\title{
Metal Contamination of an Underground Gold Picking Zone in the Department of Djekanou, Cote D'Ivoire
}

\author{
Ouattara Bakary ${ }^{1,}$, Aka Ané Maurice², Yao Kouakou Alphonse ${ }^{3}$, Seka Yapoga Jean ${ }^{4}$, \\ Gnagne Essoh Yves ${ }^{4}$, Yapo Ossey Bernard ${ }^{4}$ \\ ${ }^{1}$ Polytechnic Doctoral School, Yamoussoukro, Ivory Coast \\ ${ }^{2}$ UFR of Earth Sciences and Mineral Resources (ESMR), Felix Houphouet-Boigny University, Abidjan, Ivory Coast \\ ${ }^{3}$ National Polytechnic Institute Félix Houphouet-Boigny (INPHB), Yamoussoukro, Ivory Coast \\ ${ }^{4}$ UFR Environmental Sciences and Management, Laboratory of Environmental Sciences, Nangui Abrogoua University, Abidjan Ivory Coast
}

Email address:

danvobekah@gmail.com (O. Bakary)

${ }^{*}$ Corresponding author

\section{To cite this article:}

Ouattara Bakary, Aka Ané Maurice, Yao Kouakou Alphonse, Seka Yapoga Jean, Gnagne Essoh Yves, Yapo Ossey Bernard. Metal Contamination of an Underground Gold Picking Zone in the Department of Djekanou, Cote D'Ivoire. International Journal of Environmental Monitoring and Analysis. Vol. 9, No. 1, 2021, pp. 1-10. doi: 10.11648/j.ijema.20210901.11

Received: December 5, 2020; Accepted: December 14, 2020; Published: January 22, 2021

\begin{abstract}
Illegal gold mining has developed in recent years in the department of Djékanou with the rising cost of gold on the world market, due to the slump in local agricultural products and the unemployment of young people of working age. It has become an essential activity along with agriculture and farming in rural areas. It is an effective way to fight poverty. However, this practice is likely to cause significant environmental damage. Thus, to assess the environmental quality of this region prone to gold mining activity, the determination of the level of metallic contamination of environmental matrices (soils and sediments) was carried out. Four (4) soil and sediment sampling campaigns took place in dry and rainy seasons on the illegal gold mining site and near the dam, all located at about $685 \mathrm{~m}$ from Yobouékro, on the gold washing site of Taffissou at $3,425 \mathrm{~m}$ from Djékanou and at Groudji in the department of Djékanou. The sediment sampling was carried out by Strahler's method, while that of the soils was taken at random over the extent of the gold washing sites. The total concentrations of metals in the different matrices were determined by atomic absorption spectrophotometry (AAS). The analytical results show that the metal contents are lower than the natural content of each element in the earth's crust (UCC). Gold mining activities are not currently a source of metallic contamination of the environment. Also, the contamination factors recorded from the concentrations of metals are all less than 1, indicating low contamination of sediments and soils by trace metal elements despite intense gold mining activity. Notwithstanding, the evaluation of the environmental quality from the concentrations of the metals $\mathrm{Cd}, \mathrm{Co}, \mathrm{Cr}$, $\mathrm{Hg}$ and $\mathrm{Pb}$ compared to the American guide values SQGs (TEC and PEC), it is noted that the receiving environment is contaminated only by mercury, cadmium and cyanide; the values of the other parameters studied being lower than the guide values. The two matrices mentioned above were also assayed with cyanide and the results revealed that the sites of Groudji and Taffissou are contaminated.
\end{abstract}

Keywords: Trace Elements, Physicochemistry, Geology, Gold Panning, Environment

\section{Introduction}

Gold panning is a largely informal activity that is carried out without planning, using methods and tools that are often ancestral and rudimentary, a poorly known resource [1]. Long criticized for its devastating social and environmental impacts, gold panning continues to spread throughout the world, especially in Africa. The expansion of this activity in West Africa is due to the decline in sales of traditional agricultural products (cocoa and coffee) and the ignorance of its negative medium- and long-term impacts on the biophysical and human environment by most of the actors involved in the sector [2]. The pollution generated, particularly by cyanides and mercides, is a major problem for 
gold miners and the population living near mining sites. Exposed to these chemical compounds, gold miners develop pulmonary or neurological pathologies [3].

In Côte d'Ivoire, rural populations from all regions of the country practice this activity. Gold panning tends to be seasonal with a resurgence after the end of the harvest. But for the past few years, this activity has been carried out all year round due to the slump in sales of agricultural products and the lack of jobs for the working-age population. In terms of the natural environment, physical degradation can be observed on the sites due to the installation and activities of gold panners.

The department of Djékanou, located in the center of Côte d'Ivoire, is not to be outdone by this scourge, as gold panning activity is highly developed there. The entire natural ecosystem is impacted with its corollaries that are the devastation of plantations, the coloring of water bodies, the many galleries, the destruction of habitats for terrestrial and aquatic fauna. However, no study, to our knowledge, has been conducted in the sense of a probable contamination of environmental components (water, soil, air, flora and fauna) due to gold panning activities in this department. It is therefore necessary to carry out a chemical study on the characterization of metallic trace elements (MTE) in the environmental components of this department. Thus, the purpose of this work is to characterize the ETMs and to know the level of contamination of the environmental components of the gold panning site of the department of Djékanou in these ETMs.

\section{Equipment and Methods}

Four soil and sediment sampling campaigns took place. Two (02) during the long and short dry seasons and two (02) during the long and short rainy seasons on the three clandestine gold panning sites in the Djékanou department.

\subsection{Equipment}

This section will describe the material that was used to conduct this study.

\subsubsection{Presentation of the Study Site}

Located ten kilometers from Toumodi in central Côte d'Ivoire, the Djékanou region is prone to illegal gold panning.

\subsubsection{Study Equipment}

Two types of equipment were used: technical and biological equipment.

Technical equipment (apparatus, sampling equipment and laboratory)

1. SPSS Statistics, Microsoft Excel, Arcview and Google Earth software for data processing;

2. The spectrophotometer Perkin Elmer FIAS 100 coupled with Winlab software for reading metal concentration values and the ICP OES branded PERKIN ELMER optima 2100 for metal assay.

3. A Garmin type GPS for the determination of the geographical coordinates of the sampling points;

4. Electrothermal Atomic Absorption Spectrometer (AAS) using a Varian (model AA-20) for the determination of metals.

Biological material (matrix)

Biological material concerns sediments and soils.

\subsection{Method}

The methodological approach adopted for data acquisition is as follows:

1. Initially, an exploratory study consisted of sampling all azimuthal soil and sediment over the entire study area in order to identify the most impacted sites;

2. Secondly, the most impacted sites, namely the gold panning site and the area around the Yobouékro dam, the Taffissou washing site and the gold panning site at Groudji, were sampled.

\subsubsection{Sampling}

One hundred soil and sediment samples were collected and analyzed during the first campaign of the scoping study. Subsequently, the last three soil and sediment sampling campaigns were carried out at the gold panning site and in the vicinity of the Yobouékro dam, at the Taffissou gold washing site and at the Groudji gold panning site. The four sampling campaigns correspond to the four seasons of the year that the country experiences (the great rainy season, the small dry season, the small rainy season, and the great dry season).

A total of fifty-one (51) soil samples and twenty-five (25) sediment samples were taken per campaign (or per season), or three hundred and twenty-eight (328) soil and sediment samples for all campaigns.

Sediments

Sediment samples were collected using the Strahler method, which is the most widely used flow prioritization method. It increments the order only at intersections of the same order.

It does not account for all crossings and can be influenced by the addition or deletion of crossings. The figure below illustrates the sampling methodology.

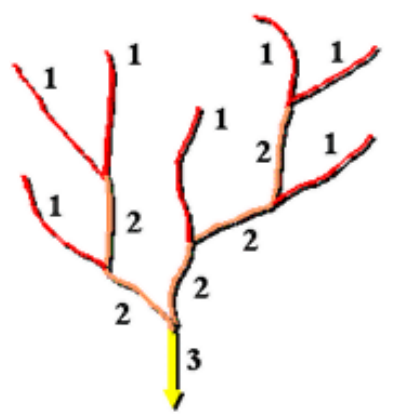

Figure 1. Sampling methodology.

This method allowed ten (10) samples to be taken in Yobouékro, two (2) in Taffissou and thirteen (13) in Groudji per campaign. 
Ten (10) soil samples were randomly collected in Yobouékro, ten (10) in Taffissou and thirty-one (31) in
Groudji. The figure below shows the sampling points in the study area:

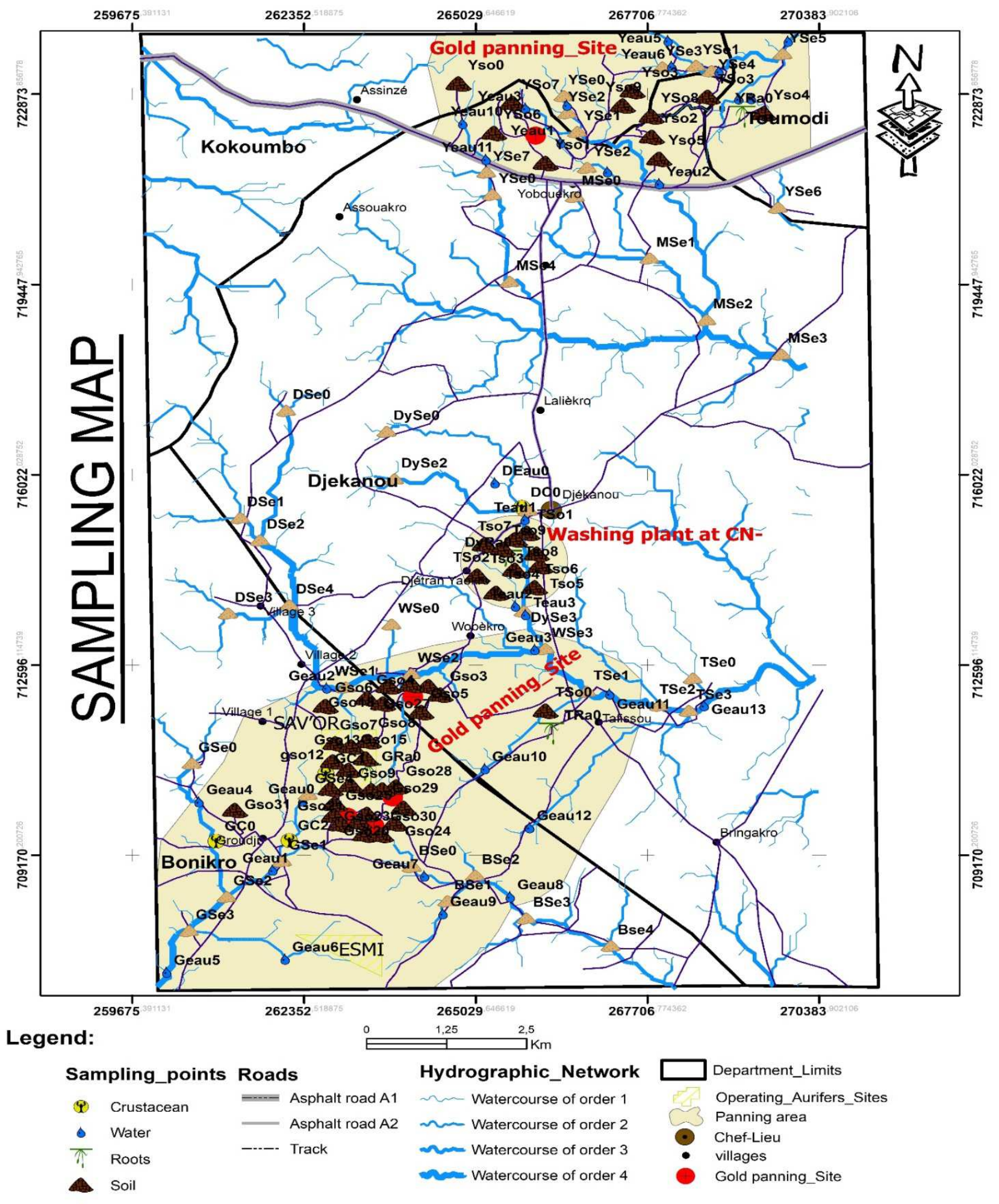

Date: $18 / 01 / 2021$

Figure 2. Sampling points in the project area.

\subsubsection{Analysis}

The sediment and soil samples were dried in the open air in the laboratory enclosure, then finely crushed and calcined at $450^{\circ} \mathrm{C}$, before being dissolved in hydrofluoric and perchloric acid according to the NF X 31-147 standard. 
After solution, the samples are filtered on wattman filter paper.

The collected filtrates are in $100 \mathrm{ml}$ vials, then made up to volume with distilled water. The filtrates are passed through the PERKIN ELMER optima 2100 ICP OES for the determination of metals such as cadmium, cobalt, chromium and lead.

For mercury, mineralization was carried out with aqua regia consisting of concentrated nitric acid and concentrated hydrochloric acid. Mineralization was carried out using an ODLAB carbon furnace at $150^{\circ} \mathrm{C}$ for 2 hours.

The samples were filtered and then assayed by flame atomic absorption spectrometry VARIAN AA240FS coupled with a hydride furnace VARIAN EL0608 according to the NF EN 1483 standard.

Concerning the cyanide, the samples, after drying and grinding, a quantity of at least $1 \mathrm{~g}$ of the grind is put in contact with $25 \mathrm{ml}$ of distilled water for 24 hours. The sample is then filtered. The cyanide is determined for each filtrate using the HACH DR 3900 spectrophotometer after the green cyanide reagents 3,4 and 5 have been added to the filtrate.

Table 1. Metal detection limit.

\begin{tabular}{ll}
\hline Parameters & Detection limit \\
\hline $\mathrm{Cd}$ & $0.2 \mu \mathrm{g} / \mathrm{L}$ \\
$\mathrm{Co}$ & $<5 \mu \mathrm{g} / \mathrm{L}$ \\
$\mathrm{Cr}$ & $<5 \mu \mathrm{g} / \mathrm{L}$ \\
$\mathrm{Hg}$ & $<0,1 \mu \mathrm{g} / \mathrm{L}$ \\
$\mathrm{Pb}$ & $<5 \mu \mathrm{g} / \mathrm{L}$ \\
\hline
\end{tabular}

\subsubsection{Contamination Factor (CF) of Sediments by Metals}

The contamination factor (FC) makes it possible to know the level of metallic contamination of sediments and soils.

It is calculated from the following relation (1):

$$
\mathrm{FC}=\mathrm{C} \text { metal / C metal background noise }
$$

With: C metal: Concentration of the metal in the sediment; Metal background: Geochemical background value for the metal. The different levels of contamination according to the FC values are grouped in the following table:
Table 2. Level of metal contamination according to FC values.

\begin{tabular}{ll}
\hline FC value & Contamination \\
\hline $\mathrm{FC}<1$ & Low contamination \\
$1 \leq \mathrm{FC}<3$ & Moderate contamination \\
$3 \leq \mathrm{FC}<6$ & Considerable contamination \\
$\mathrm{FC} \geq 6$ & Very strong contamination \\
\hline
\end{tabular}

\subsubsection{Environmental Sediment Quality Indices (TEC and PEC)}

To assess the vital quality of sediments and soils, the concentrations of metals obtained in the samples taken are compared with the American SQGs (Sediment Quality Guidelines) recently developed from a database of biological and ecological effects that could be caused by certain concentrations of pollutants in sediments and soils.

The TEC (Threshold Effect Concentration) and the PEC (Probable Effect Concentration) established by an american author are used to assess the quality of sediments and soils. These two guides are the result of a synthesis of several guides established by other authors, making them excellent tools for assessing sediment toxicity [4].

The TEC identifies contaminant concentrations below which living organisms in sediments are not affected.

The PEC identifies contaminant concentrations above which adverse effects on sediment-dwelling organisms are observed $[5,6]$. The use of these references has been effectively proven for 8 trace metals $\mathrm{As}, \mathrm{Cd}, \mathrm{Cr}, \mathrm{Cu}, \mathrm{Pb}, \mathrm{Hg}, \mathrm{Ni}$ and $\mathrm{Zn}$.

Table 3. Guide values in ug / L of TEC and PEC of metals in $\mathrm{ug} / \mathrm{g}$.

\begin{tabular}{lllll}
\hline & Cd & Cr & Hg & Pb \\
\hline TEC & 0,99 & 43,4 & 0,18 & 35,8 \\
PEC & 4,98 & 111 & 1,06 & 128 \\
\hline
\end{tabular}

To assess the environmental impacts of metallic trace elements in the gold panning area, two tools will be used, namely the contamination factor and the American guide values (TEC and PEC).

\section{Results and Discussion}

\subsection{Results}

The concentrations of TMEs in the different matrices at the gold panning and washing sites are recorded in the tables below:

\subsubsection{Metal Content in the Soil and Sediments of the Gold Mining}

Table 4. Results of analysis of MTE and cyanide in ug / L in soil and sediment samples in the project area.

\begin{tabular}{|c|c|c|c|c|c|c|c|c|c|c|c|c|}
\hline \multirow{3}{*}{ Sampling sites } & \multicolumn{12}{|c|}{ Concentration in ug / L of MTE in soil } \\
\hline & \multicolumn{7}{|c|}{ Dry seasons } & \multicolumn{5}{|c|}{ Rainy seasons } \\
\hline & Cd & Co & $\mathrm{Cr}$ & Hg & $\mathrm{HCN}$ & $\mathbf{P b}$ & Cd & Co & $\mathrm{Cr}$ & $\mathbf{H g}$ & HCN & $\mathbf{P b}$ \\
\hline Yobouékro (dam) & 0,2 & 12 & 31,41 & 0,9 & 1,02 & 15,9 & 0,7 & 12,5 & 35,01 & 1,13 & 4,009 & 16,42 \\
\hline Yobouékro (gold panning site) & 0,8 & 20 & 38,2 & 3,8 & 0,004 & 16,53 & 0,9 & 22,6 & 43,71 & 4,25 & 0,017 & 17,82 \\
\hline Taffissou (washing site) & 0,09 & 14 & 36,3 & 1,86 & 1,19 & 12,58 & 0,5 & 15,7 & 37,90 & 2,03 & 6,73 & 14,25 \\
\hline $\begin{array}{l}\text { Groudji (gold washing site and semi-industrial exploitation } \\
\text { plots of SAVO'R and ESMI) }\end{array}$ & 0,1 & 11 & 32,9 & 1,15 & 0,9 & 8,17 & 0,1 & 10,5 & 33,15 & 3,15 & 1,209 & 10,38 \\
\hline UCC (natural content of each element in the earth's crust) & 0,1 & 17 & 35 & 0,06 & $\begin{array}{l}<0,005 \\
-0,5\end{array}$ & 17 & 0,1 & 17 & 35 & 0,06 & $\begin{array}{l}<0,005 \\
-0,5\end{array}$ & 17 \\
\hline Concentration in ug / L of MTE in sediments & & & & & & & & & & & & \\
\hline
\end{tabular}




\begin{tabular}{|c|c|c|c|c|c|c|c|c|c|c|c|c|}
\hline \multirow{3}{*}{ Sampling sites } & \multicolumn{12}{|c|}{ Concentration in ug / L of MTE in soil } \\
\hline & \multicolumn{7}{|c|}{ Dry seasons } & \multicolumn{5}{|c|}{ Rainy seasons } \\
\hline & Cd & Co & $\mathbf{C r}$ & $\mathrm{Hg}$ & $\mathrm{HCN}$ & $\mathbf{P b}$ & Cd & Co & $\mathbf{C r}$ & $\mathrm{Hg}$ & HCN & $\mathbf{P b}$ \\
\hline Sampling sites & $\mathrm{Cd}$ & Co & $\mathrm{Cr}$ & $\mathrm{Hg}$ & $\mathrm{HCN}$ & $\mathrm{Pb}$ & $\mathrm{Cd}$ & Co & $\mathrm{Cr}$ & $\mathrm{Hg}$ & $\mathrm{HCN}$ & $\mathrm{Pb}$ \\
\hline Yobouékro (dam) & 0,4 & 15,36 & 33,08 & 1,12 & 1,304 & 17,12 & 0,9 & 17,15 & 34,05 & 1,12 & 3,016 & 17,12 \\
\hline Yobouékro (gold panning site) & 0,9 & 22,01 & 39,16 & 2,49 & 0,009 & 14,49 & 1,5 & 20,35 & 41,08 & 2,51 & 0,028 & 14,49 \\
\hline Taffissou (washing site) & 0,1 & 17,53 & 34,13 & 3,59 & 2,67 & 15,07 & 0,2 & 18,13 & 36,42 & 3,57 & 4,012 & 15,07 \\
\hline $\begin{array}{l}\text { Groudji (gold washing site and semi-industrial exploitation } \\
\text { plots of SAVO'R and ESMI) }\end{array}$ & 0,1 & 10,32 & 34,41 & 1,16 & 1,234 & 15,26 & 0,1 & 12,45 & 33,27 & 2,06 & 2,065 & 15,26 \\
\hline UCC (natural content of each element in the earth's crust) & 0,1 & 17 & 35 & 0,06 & $\begin{array}{l}<0,005 \\
-0,5\end{array}$ & 17 & 0,1 & 17 & 35 & 0,06 & $\begin{array}{l}<0,005 \\
-0,5\end{array}$ & 17 \\
\hline
\end{tabular}

The analysis in Table 4 shows, on the one hand, that with the exception of lead, the concentrations of MTEs (cadmium, cobalt, chromium, mercury and cyanide) in soil and sediment samples taken near the dam and at the Yobouékro gold panning site at the Taffissou gold washing site during the dry and rainy seasons are generally higher than the natural content of each element in the earth's crust (UCC); which shows that the samples collected in the study area are affected by existing anthropogenic activities. This pollution is more noticeable with mercury and cyanide due to their strong involvement in gold panning activity:

- Thus, mercury varies from 0.9 to $3.59 \mathrm{ug} / \mathrm{L}$ while its UCC value is $0.06 \mathrm{ug} / \mathrm{L}$;

- cyanide ranges from 0.004 to $6.73 \mathrm{ug} / \mathrm{L}$ while its UCC value is $<0.005-0.5 \mathrm{ug} / \mathrm{L}$;

- the cadmium concentration varies from 0.09 to $1.5 \mathrm{ug} / \mathrm{L}$ while its $\mathrm{UCC}$ value is $0.1 \mathrm{ug} / \mathrm{L}$;

- cobalt varies from 10.32 to $22.6 \mathrm{ug} / \mathrm{L}$ while its $\mathrm{UCC}$ value is $17 \mathrm{ug} / \mathrm{L}$;

- chromium varies from 31.41 to $43.71 \mathrm{ug} / \mathrm{L}$ while its UCC value is $35 \mathrm{ug} / \mathrm{L}$;

- and lead ranges from 8.17 to $17.82 \mathrm{ug} / \mathrm{L}$ while its UCC value is $17 \mathrm{ug} / \mathrm{L}$.

The concentrations are higher in the wet season than in the dry season. This seems to be normal because heavy rainfall facilitates the processes of run-off and infiltration of water. This water drains quantities of pollutants, especially MTEs from wild deposits. On the other hand, the gold panning site and the semi-industrial mining plots of SAVO'R and ESMI in Groudji are not affected by MTEs because they are regularly visited by the Mining Administration.

\subsubsection{Level of Contamination of the Environment of Gold Mining and Washing Sites by Metals}

The Contamination Factor (CF) provides information on the level of metallic contamination of soils and sediments in gold panning and washing sites. The following figures show the distribution of the sediment and soil contamination factors.

Overall, it can be seen that the contamination factors recorded from the concentrations of MTEs in the soils and sediments of the gold panning and washing sites in the Djékanou area show very varied levels of contamination.

i. Near the Yobouékro Dam

The soils and sediments collected at the dam are considerably $(\mathrm{FC}=7)$ to very heavily $(\mathrm{FC}=9)$ contaminated with cadmium.
For $\mathrm{Cr}(\mathrm{FC}=0.97$ and 1$), \mathrm{Co}(\mathrm{FC}=0.73$ and 1$)$ and $\mathrm{Pb}$ ( $\mathrm{FC}=0.96$ and 1$)$, the contamination factors obtained are less than or equal to 1 , showing a low contamination by these MTAs.

The cyanide contamination factors are in the range of 2 to 8 ( $\mathrm{FC} \geq 6$ ), indicative of very high contamination.

For mercury, the contamination factors of 18.83 and 18.66, well above 6 , show very high mercury contamination.

ii. On the Yobouékro gold panning site

Soils and sediments collected from the gold panning site are considerably $(\mathrm{FC}=9)$ to very heavily $(\mathrm{FC}=15)$ contaminated with cadmium.

For $\mathrm{Cr}(\mathrm{FC}=1.24$ and 1.19), $\mathrm{Co}(\mathrm{FC}=1.32$ and 1.17) and $\mathrm{Pb}$ $(\mathrm{FC}=1.04$ and 0.85$)$, the contamination factors are either $\mathrm{FC}$ $<1$ or $1 \leq \mathrm{FC}<3$. The sediments and soils analyzed are slightly to moderately contaminated by these MTAs.

Cyanide contamination factors are in the range of 0.004 to $0.017(\mathrm{CF}<1)$, indicating that the soils and sediments at the Yobouékro gold panning site are slightly contaminated.

$\mathrm{Hg}$ CFs of 70.83 and 41.5 , greater than 6 , indicate very high mercury contamination.

iii. On the Taffissou gold washing site

Soils and sediments collected at Taffissou are slightly $(\mathrm{FC}=5)$ to moderately $(\mathrm{FC}=1.06)$ contaminated with cadmium.

For $\mathrm{Cr}(\mathrm{FC}=1.04$ and 1.08), $\mathrm{Co}(\mathrm{FC}=0.92$ and 1.06) and $\mathrm{Pb}$ ( $\mathrm{FC}=0.83$ and 0.88 ), the contamination factors are either $\mathrm{FC}$ $<1$ or $1 \leq \mathrm{FC}<3$. The sediments and soils analyzed are slightly to moderately contaminated by these MTAs.

Cyanide contamination factors are in the range of 2.006 to $3.36(1 \leq \mathrm{FC}<3$ and $(3 \leq \mathrm{FC} \geq 6)$. Soils and sediments at the Taffissou gold wash site are moderately to highly contaminated.

FCs for $\mathrm{Hg}$ of 33.83 and 59.8 above 6 indicate very high mercury contamination.

iv. Groudji.

Cyanide contamination factors are on the order of 1.8 to $4.0(1 \leq \mathrm{FC}<3$ and $3 \leq \mathrm{FC}<6)$. This presents a case of very highly contaminated soils and sediments.

Mercury contamination factors are of the order of 19 to 34 ( $\mathrm{FC} \geq 6$ ). This presents a case of moderately to considerably contaminated soils and sediments.

The FCs of the other MTEs obtained in the soils and sediments sampled in Groudji, less than or equal to 1, show low contamination by these MTEs. 


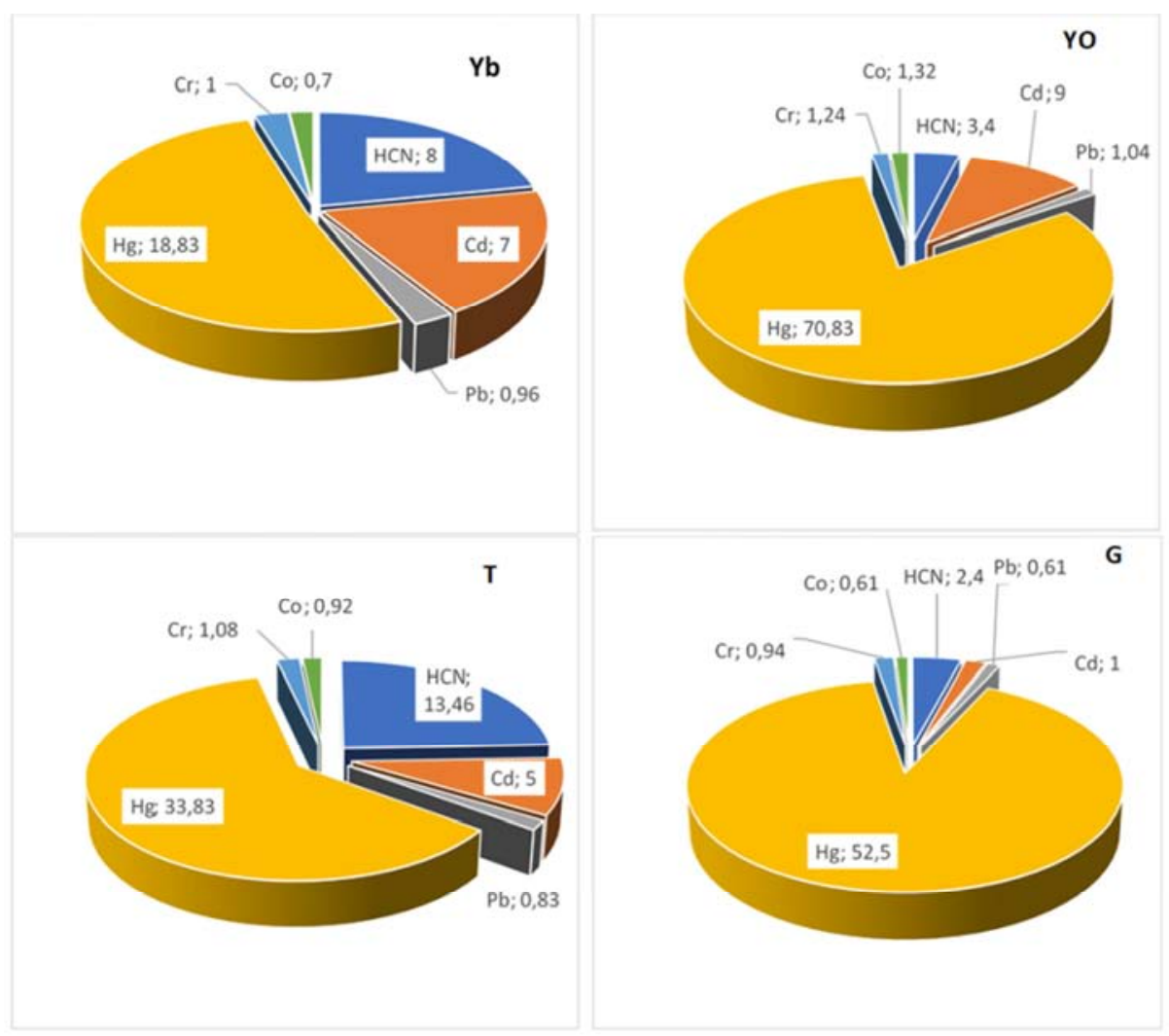

Figure 3. Distribution of soil contamination factors.

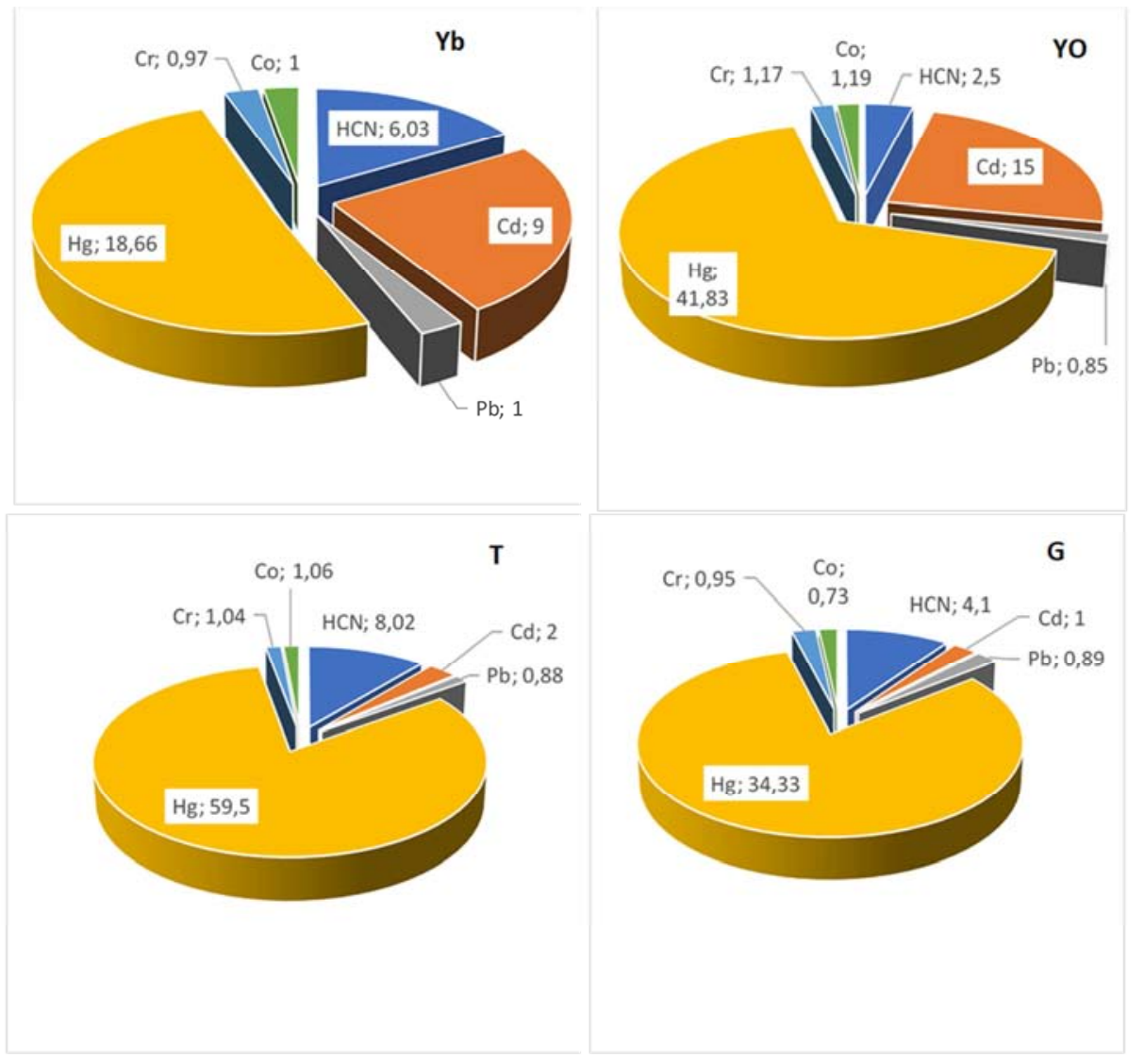

Figure 4. Distribution of sediment contamination factors. 


\subsubsection{Assessment of the Environmental Quality of the Gold} Mining Area

The levels of ETMs $(\mathrm{Cd}, \mathrm{Cr}, \mathrm{Hg}, \mathrm{Pb})$ in the sediments and soils on the gold panning sites and its surroundings were compared to the American SQGs (TEC and PEC) guide values in order to avoid environmental impact.
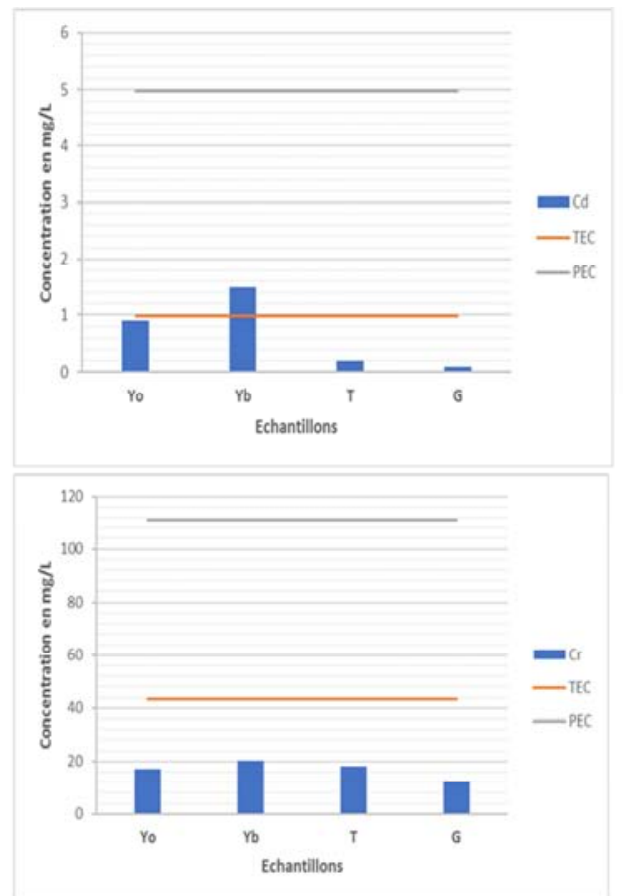

Figure 5. Comparison of MTEs to TEC / PEC of soils in the gold mining zone.
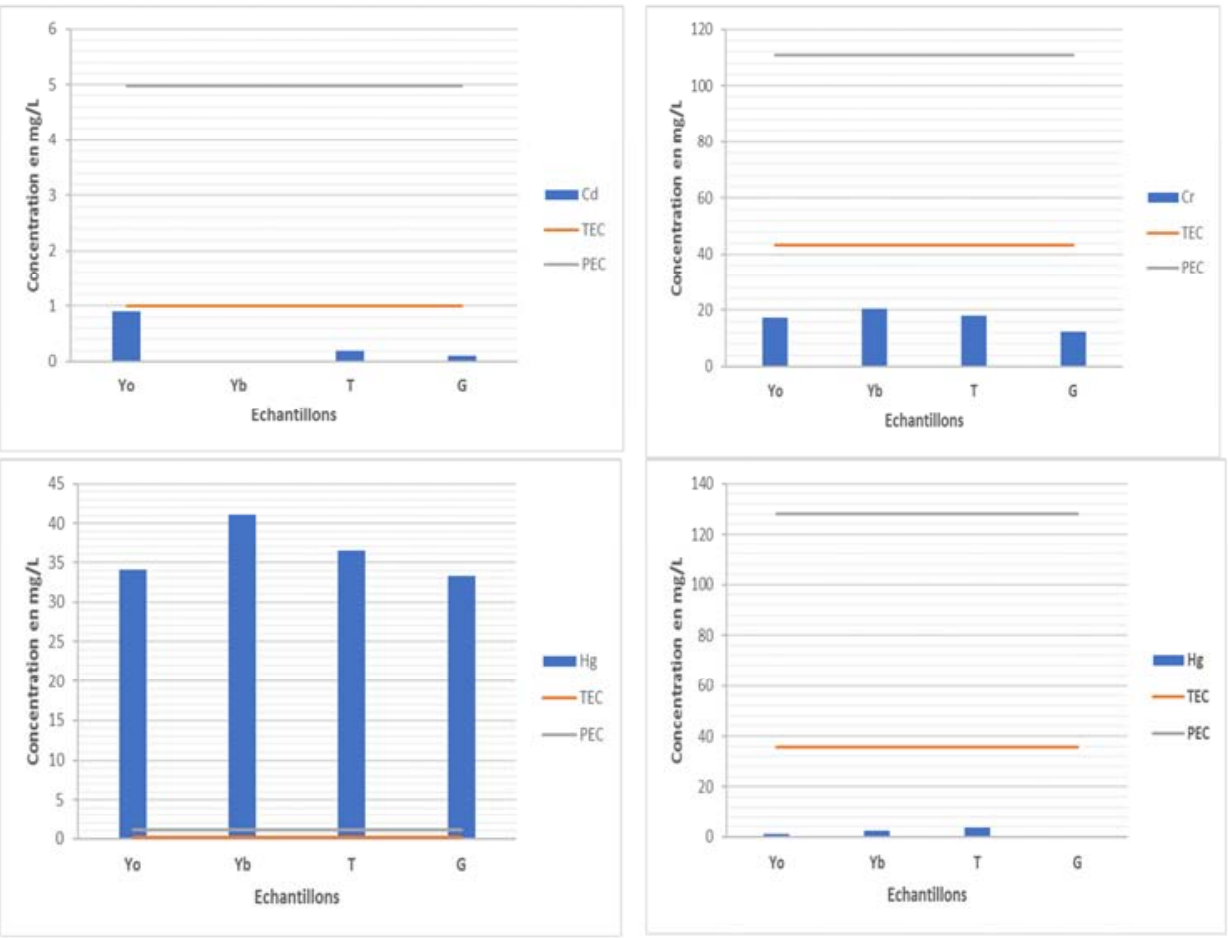

NB: Yobouékro (gold panning site): Yo, Yobouékro (dam): Yb, Taffissou (washing site): T and Groudji: G

Figure 6. Comparison of MTEs to TEC / PEC of sediments in the gold mining zone. 


\subsection{Discussion}

Analysis of the results shows that, of the three gold panning and washing sites that were the subject of this study in the Djékanou region, the Yobouékro and Taffissou sites are affected by MTAs, with the Groudji site being uncontaminated. Thus, the concentrations of MTAs $(\mathrm{Cd}, \mathrm{Co}$, $\mathrm{Cr}, \mathrm{Hg}, \mathrm{HCN}$ and $\mathrm{Pb}$ ) in the soils and sediments determined are lower than the natural content of each element in the earth's crust (UCC) except for mercury, cyanide and cadmium. The concentration of cadmium is high during the rainy season. Cadmium, which is very soluble in water, is leached out and will therefore be very weakly bound to organic matter in sediments and soil [7]. This dissolution of $\mathrm{Cd}$ will increase its concentration in runoff water and in the surrounding watercourses, which constitutes a risk for the population using these waters. Mercury, on the other hand, is a toxic metal that is dangerous to humans if consumed. It causes incurable diseases. A recent study conducted in Burkina Faso by the United Nations Environment Programme [8], showed that the prevalence of symptoms, including frequent headaches, sleep disturbances, unusual fatigue, trembling and visual disturbances, was higher among people who either prepare and heat gold-mercury amalgams or trade and sell gold. Some Ivorian authors have worked on the assessment of metallic pollution of ground and surface water in a highly active gold mining environment at Hiré in Ivory Coast resulted in higher concentrations of VTE than in the present study. From 0.09 to $1.5 \mathrm{ug} / \mathrm{L}$ versus 78 to 385 $\mathrm{ug} / \mathrm{L}$ for $\mathrm{Cd}$; from 31.41 to $43.71 \mathrm{ug} / \mathrm{L}$ versus 1 to $81 \mathrm{ug} / \mathrm{L}$ for $\mathrm{Cr}$; from 0.06 to $3.59 \mathrm{ug} / \mathrm{L}$ versus 17 to $745 \mathrm{ug} / \mathrm{L}$ for $\mathrm{Hg}$; and from 8.17 to $17.82 \mathrm{ug} / \mathrm{L}$ versus 1.5 to $255.5 \mathrm{ug} / \mathrm{L}$ for $\mathrm{Pb}$ [9].

The high concentrations found in the samples in the vicinity of the Hiré mine could be explained by the contamination of seepage water from the mine's rock debris stockpile [10]. The difference in the results of these studies could be explained by the nature of the matrices and the intensity of gold panning activities at Hiré and Djékanou.

The presence of TMEs found on the various gold panning sites in Djékanou is thought to be due to poor waste management (batteries and used oil), whereas in Hiré, the leaching of rocks and sediments is one of the causes of the high presence of sodium, cadmium, mercury and nickel in the surface water. One study was done on the rocks and sediments found in most gold deposits contain sodium and mercury (HgS) compounds, while the other study discovered the presence of cadmium and nickel compounds in the rocks and sediments of gold deposits [11, 12].

The high concentrations of TMEs detected in the sediments and water of the "Nabion" River at Katiola, result in the high level of contamination of the different sampling zones [13]. These VTEs come not only from the nature of the soil but also from the practices of gold diggers who dig the soil at great depths and use non-standard techniques, notably the use of mercury, which is separated from the ore by evaporation. In addition to this threat, dust from crushing and grinding are sources of environmental pollution.

In general, toxic metals such as cadmium and lead have been detected in abundance in areas where gold panning activities are in full swing (washing of tailings and concentration of gold).

This shows the influence of these on the values of the concentrations of toxic metals. This is consistent with the results of, which showed that gold mining activities are highly polluting and are potential sources of toxic TMEs [14, 15].

Surveys of village communities in Djékanou revealed that gold panning activities that began in 2012 in Mougnan and in 2014 in Groudji, two villages in the area, have at times experienced periods of calm due to clearance actions by the Brigade for the Repression of Infringements of the Mining Code (BRICM) of the Ministry in charge of mines; this explains the low contamination of the ecosystem of the gold panning area by metals. The high contamination of the Hiré mining sites is a crucial and worrisome environmental problem given the large flow of these elements, their toxic nature and especially their high capacity to accumulate in the biota [16]. These chemicals can cause the extinction of certain animal and/or plant species and consequently, lead to the malfunctioning of the food chain [17]. The concentrations of cadmium and mercury compared to the American SQGs (TEC and PEC) have shown that the environmental quality of the gold panning area in Djékanou is affected only by these two elements. MTA levels in sediments and soils are below the TEC and PEC for chromium and lead. The concentrations of these ETMs, which are sometimes higher than these guide values, found in the sediments of the Hiré mine and the two gold panning sites in Djékanou, constitute real sources of exposure for the local populations and the species living there. The possibility of accumulation of MTAs, along the food chain, in aquatic, plant, animal and human organisms is to be feared, due to the bioaccumulative capacities of these elements.

The release of cyanide into the environment leads to the death and intoxication of the aquatic life of rivers and the predators that depend on them and make it difficult for the water unfit for consumption. The limit concentration of cyanide in the environment aquatic is approximately $5 \mu \mathrm{g} / \mathrm{L}$ [18]. At this concentration living in water have their metabolism inhibited.

The cyanidation method used in Taffissou is the same as that practiced in Zougnazagmline in Burkina Faso.

The method consists of extracting gold from the ores in basins using a cyanide solution accompanied by sulfuric and nitric acid and then zinc shavings. The cyanide-gold liquid is directed through small orifices into U-shaped tubes containing the zinc chips and placed in the basins. The zinc is recovered after three days and incinerated to obtain gold. The sterile sludge is discharged into the receiving environment, thus polluting the environment [19].

The Taffissou gold washing site is of concern because of its level of cyanide contamination. 


\subsection{Recommendations}

Gold panning activities cause considerable environmental degradation through inappropriate practices and the use of chemicals such as mercury and cyanide. In order to decontaminate soils and sediments in the Djékanou gold zone for agricultural purposes, the bioremediation technique can be used for cyanide, as several studies have shown that free cyanide is easily degraded by microorganisms while earthworms, due to their property as environmental bioremediators can significantly bioaccumulate trace metals while reducing the availability of mercury in feces [20-25].

\section{Conclusion}

The levels of ETM (cadmium, cobalt, chromium, mercury, cyanide and lead) analyzed in the soils and sediments of the Yobouékro and Groudji gold panning area and at the Taffissou washing site during the dry and rainy seasons showed that only mercury and cadmium have levels higher than the natural content of each element in the earth's crust (UCC).

This exposes the area to contamination despite a reduction in the intensity of gold panning activity in the last two years due to the withdrawal of illegal gold panners by the Ministry of Mines. The levels of ETMs $(\mathrm{Cd}, \mathrm{Co}, \mathrm{Cr}, \mathrm{Hg}, \mathrm{Pb})$ in the sediments and soils at and around the illegal gold panning sites compared to the US SQGs (TEC and PEC) guide values for environmental impact assessment revealed that mercury and cadmium could contaminate existing flora and fauna. Plants growing on polluted soils could contaminate and create risks throughout the food chain.

\section{Acknowledgements}

We express our sincere thanks to UMRI 68 and its Laboratory of Civil Engineering, Geosciences and Geographic Science, then to the Polytechnic Doctoral School and to the National Polytechnic Institute Félix HouphouëtBoigny, Yamoussoukro, d'Ivory Coast, to the Ivorian Center of Antipollution and its Central Environmental Laboratory, the ENVAL Cabinet and its laboratory.

\section{References}

[1] Jacques, E., Orru, J.-F., and Pelon, R. (2005). Sustainable development: what place for the artisanal mine. Geoscience $\mathrm{N}^{\circ}$ 1 January 2005 page $67-70$.

[2] Goh Denis, 2016).

[3] Joseph Bohbot, 2017).

[4] Macdonald D. D, Ingersoll C. G. and Berger T. A. (2000). Development and evaluation of consensus-based sediment quality. guidelines for freshwater ecosystems. Arch. About. Con. Tox. 39: 20-31pp.

[5] Long E. R., Macdonald D. D., Smith S. L. and Calder F. D. (1995). Incidence of adverse biological effects within ranges of chemical concentrations in marine and estuarine sediments.
About. Management 199: 81-97.

[6] Ingersoll C. G., Haverland P. S., Brunson E. L., Canfield T. J., Dwyer F. J., Henke C. E., Kemble N. E., Mount D. R. and Fox R. G. (1996). Calculation and evaluation of sediment effect concentrations for the amphipod Hyacellaazteca and the midge Chironomusriparius. J. Great lakesres. 22 pp. 2-623.

[7] Camobreco et al., 1996.

[8] UNEP. (2007). Manual of sediment sampling and analysis. UNEP (DEPI) / MED WG. 321 / Inf. 4, 26p.

[9] Y. H. A. Yapi, B. K. Dongui, A. Trokourey, Y. S. S. Barima, Y. Essis and P. Atheba 2014. Evaluation of metallic pollution of underground and surface water in a gold mining environment in Hiré (Ivory Coast), Available online at http://ajol.info/index. php / ijbcs. Int. J. Biol. Chem. Sci. 8 (3): 1281-1289, June 2014. ISSN 1997-342X (Online), ISSN 1991-8631 (Print).

[10] Atse ARM., (2007). Environmental impact study of the Bonikro gold project in Ivory Coast. French speaking Institute of Energy and Environment, moged technical sheet.

[11] Miramond N, Miau D, and Brochard F. 2006. Diagnosis of the Acid Mining Drainage phenomenon on primary gold mines in French Guyana: Assessment of associated risks, Report, GEM Impact- DIREN, French Guyana.

[12] N'guessan YM. 2008. Dynamism of trace elements without surface water in the agricultural watersheds of Cascogne. Doctoral thesis, Institut national polytechnique de Toulouse (INPT), University of Toulouse, Toulouse, p. 253.

[13] Koné Mohamed., 2014. Assessment of the level of contamination of the "Nabion" river by ETM $(\mathrm{Fe}, \mathrm{Zn}, \mathrm{Cu}, \mathrm{Cd}, \mathrm{Pb})$ resulting from gold washing work, in the Department of Katiola.

[14] Thesis to obtain the Diploma of Advanced Studies in Environmental Sciences and Management OPTION: Chemistry, Health and Environment, 69 pages, defended on July 29, 2014.

[15] Jung M. C., 2001. Heavy metal contamination of soils and waters in and around the lmcheon Au-Agmine, Korea; 16: 1369-75.

[16] Navarro M. C., Perez-Sirvent C., Martmez-Sanchez M. J., Vidal J., Tovar P. J. and Bech J., 2008. Abandoned mine sites as a source of contamination by heavy metals: A case study in a semi-arid zone. GeochemExplor; 96: 183-93.

[17] Coulibaly A. S., Monde S., Wognin A. V., Aka K. (2009). Analysis of Metallic Trace Elements (MTE) in estuarine bays of Abidjan in Ivory Coast, Africa SCIENCE 05 (3) PP 77-96.

[18] Gold, 2002. Mixed Dementia: Epidemiology, Diagnosis, and Treatment, Vol. 50, Issue 8, Pages: 1321-1467, August 2002, Journal of the American Geriatrics Society (JAGS).

[19] Logsdon et al, 1999. Quality of life in Al Zheimer's Disease. Patient and Caregiver Reports, University of Washington, Vol. 5, No. 1, 1999.

[20] Joël ROAMBA, 2014. Environmental and health risks on gold mining sites in Burkina Faso: life cycle of the main pollutants and perceptions of gold washers (case of the Zougnazagmligne site in the rural commune of Bouroum, central-north region) obtaining the master's degree in water and environmental engineering, Option: water and sanitation, page 40-42, defended on October 13, 2014. 
[21] Akinpelu et al., 2015. Physical, functional, pasting and thermal properties of flours and starches of six Nigerian rice cultivars, vol. 44, February 2015, PP 478-490.

[22] LuqueAlmagro et al., 2016. Biodegradation of cyanide wastes from mining and jewellery industries, April 2016, Current Opinion in Biotechnology 38: 9-3.

[23] Mirizadeh et al., 2014. Biodegradation of cyanide by a new isolated strain under alkaline conditions and optimization by response surface methodology (RSM), May 2014, Journal of Environmental Health Science and Engineering 12 (1): 85.
[24] Razanamahandry et al., 2016. Biodegradation of free cyanide by bacterial species isolated from cyanide-contaminated artisanal gold mining catchment area in Burkina Faso, August 2016, Chemosphere 157: 71-78

[25] Lihong Liu, Yu Zhang, Zhaojun Yun, Bin He, Guibin, Jiang 2016. Estimation of bioaccessibility and potential human health risk of mercury in Chinese patent medicines, Journal of Environmental Sciences, Volume 39, January 2016, Pages 3744. 